\title{
Treatment of the acute bronchitic exacerbation
}

\author{
GORDON EDWARDS, D. J. CHARLEY, E. E. KEAL, AND E. C. FEAR \\ From Leeds Chest Clinic and Department of Respiratory Diseases
}

Bronchitis accounts for rather less than $10 \%$ of all the sickness absence from industry, and acute exacerbations of chronic bronchitis constitute the greater proportion of this. Many of these exacerbations are sequels of upper respiratory tract infections; the head cold 'going down to the chest' is a frequent complaint of many bronchitics. We find there is usually an interval of about 12 to 48 hours between the start of the head cold and the appearance of increased chest symptoms, which are probably due to bacterial superinfection of the bronchial tree.

Ritchie (1958) had suggested that antibiotics administered at the beginning of a head cold prevented secondary bacterial invasion of the bronchi. Because of this and of our failure (Fear and Edwards, 1962) to demonstrate any statistically significant benefit from intermittent antibiotic therapy of the fully developed acute chest exacerbation, we have assessed the value of a short course of antibiotic therapy when started immediately at the first indication of a head cold but before change in the chest symptoms has occurred. Since some of the cheaper antibacterial drugs are as effective in the long-term management of chronic bronchitis as the broad spectrum antibiotics, it was planned to compare an oral penicillin, $\mathbf{K}$ phenoxymethyl penicillin, with oxytetracycline and with a blank dummy substance. The therapeutic agents were to be used either continuously each day throughout the winter months, or intermittently for a few days only, taken immediately at the start of a head cold and before the onset of a chest exacerbation, or

\section{TABLE I}

THERAPEUTIC REGIMES UNDER TEST

\begin{tabular}{|c|c|c|}
\hline $\begin{array}{l}\text { Treatment } \\
\text { Group }\end{array}$ & Continuous Therapy & Intermittent Therapy \\
\hline $\begin{array}{l}\mathbf{A} \\
\mathbf{B} \\
\mathbf{C} \\
\mathbf{D} \\
\mathbf{E} \\
\mathbf{F}\end{array}$ & $\begin{array}{l}\text { Penicillin }^{1} \\
\text { Oxytetracycline }^{2} \\
\text { Dummy oxytetracycline } \\
\text { Dummy oxytetracycline } \\
\text { Dummy penicillin } \\
\text { Dummy penicillin }\end{array}$ & $\begin{array}{l}\text { Dummy oxytetracycline } \\
\text { Dummy penicillin } \\
\text { Dummy penicillin } \\
\text { Penicillin } \\
\text { Oxytetracycline }^{2} \\
\text { Dummy oxytetracycline }\end{array}$ \\
\hline
\end{tabular}

at the inception of prodromal symptoms of any other episode which, in the patient's experience, is likely to be followed by an exacerbation of his bronchitis. Since both real and indistinguishable dummy capsules of each preparation were being used, six treatment regimes were investigated, employing a double blind technique (Table I).

\section{MATERIALS AND METHODS}

The names of patients, who had been under observation for 12 to 36 months and had agreed to take part in the trial, were allocated by an independent assessor to treatment groups from prepared lists of random numbers and therapeutic regimes, so that the two dummy control groups together were equal to each of the active treatment groups. The criteria for diagnosis and entry into the trial, the methods of follow-up and conduct of the investigation, and the definition of the terms used were those described previously (Fear and Edwards, 1962). In addition, ventilatory function was estimated on admission to the trial, at the start of treatment, and at each attendance throughout the investigation. The response to treatment was to be estimated by comparing the number of individual episodes experienced by the patients, i.e., head colds, acute chest exacerbations, occasions of confinement to bed or periods off work, and admission to hospital as a result of bronchitis, with the number of such episodes experienced in the comparable period in the previous winter, which had been observed and recorded at the time. Finally a numerical assessment was made at the end of the trial, employing a simple marking system as follows: for each head cold, 5 marks; for each chest exacerbation, of 10 marks; for each period confined to bed, 25 marks; and for each hospital admission, 50 marks. By deducting the total score obtained during the six months of $\mathrm{N}$ the trial from the score obtained in the comparable six months of the previous winter, each patient could be allotted a plus or minus score, and mean scores for each treatment group could then be determined.

On admission to the trial in September 1959, each patient was given the following written instructions:

'Two different types of capsule will be used to treat your bronchitis. One type is for continuous treatment and the packet is marked with a green star. The other type is for intermittent treatment only, as instructed below, and this packet is marked with a red star. 
Packet marked "Continuous" with a green star

1 Take these capsules every day during the winter from mid-October to mid-April.

2 Two capsules are to be taken after breakfast and two after supper, making four every day. You must not take extra doses.

Packet marked "Intermittent" with a red star

1 This packet contains a different type of special capsule, which is for use when you start a cold in the head. Two capsules should be taken immediately at the start of a head cold, that is, within an hour or two of starting and before it has gone down to your chest, or if you feel that you are likely to get a flareup of your bronchitis.

2 Continue to take these capsules, four each day, two after breakfast, and two after supper, continuing for seven days only. If you are then quite well again you can stop them. If, in spite of taking the special capsules, your chest gets worse, you should consult your own doctor.

3 These capsules should not be taken at any other time.

4 Don't stop taking the continuous daily capsules, and carry on with the continuous capsules after your chest is better. Don't open a fresh red-starred packet unless you develop another cold.'

The intention to begin intermittent therapy within an hour or two of starting a head cold and continuing for seven days only was understood by all 105 patients who commenced treatment in mid-October 1959. Table II indicates the sex, age groups, and treatment regimes of the patients admitted to the study. It also shows those patients who failed to complete the trial.

TABLE II

DISTRIBUTION OF PATIENTS ACCORDING TO THERAPEUTIC REGIMES

\begin{tabular}{lcccccc}
\multicolumn{7}{c}{ Treatment Group } \\
\cline { 2 - 7 } & $A$ & $B$ & $D$ & $E$ & $C+F$ & Total \\
\hline Males under 40 & $3^{*}$ & 2 & 1 & 2 & 3 & 11 \\
Males over 40 & $16^{* *}$ & 15 & $17^{* * *}$ & $15^{*}$ & $18^{* * *}$ & 81 \\
Females under 40 & -1 & 1 & -2 & 1 & 1 & 3 \\
Females over 40 & 1 & 2 & 2 & 2 & 3 & 10 \\
Total males & 19 & 17 & 18 & 17 & 21 & 92 \\
Total females & 1 & 3 & 2 & 3 & 4 & 13 \\
Total admitted & 20 & 20 & 20 & 20 & 25 & 105 \\
Total finishing & 17 & 20 & 17 & 19 & 22 & 95
\end{tabular}

* One patient excluded from final analysis

\section{RESULTS}

Of the 105 patients accepted for the trial, 11 were admitted to hospital, eight from the combined control groups $\mathrm{C}+\mathrm{F}$, one from group $\mathrm{D}$, and two from group $E$. Four were still in hospital at the end of the trial after more than four weeks, or had otherwise missed two monthly assessments, and were excluded from the final analysis; two were from the combined control groups $\mathbf{C}+\mathbf{F}$ and one each was from groups D and $E$. In addition, another six patients, three from group A, two from group D, and one from combined group $\mathrm{C}+\mathrm{F}$, failed to attend regularly but were known to be well and working full time at the end of the investigation; they were excluded from the final assessment which is therefore based on the results achieved in the remaining 95 patients. No patient was withdrawn from the trial because of complications arising from the treatment regimes. Indeed, no significant side effect or toxic manifestation of any kind was observed at any time during the conduct of the investigation.

The range of the final scores was from -130 to +150 , with a median score of $+27 \cdot 5$. Since by definition every plus score indicated a measure of improvement compared with previous experience, an arbitrary base line of +30 to approximate to the median score was selected in order to provide a more sensitive index. Patients with scores above this median have had fewer exacerbations and been classified as 'improved', whereas patients with scores below the median are in this respect much the same or worse than in the previous year and have been assessed as 'not improved' (Table III).

TABLE III

RESULTS OF SIX MONTHS' CONTINUOUS OR INTERMITTENT TREATMENT

\begin{tabular}{llllll} 
Treatment Group & $A$ & $B$ & $D$ & $E$ & $C+F$ \\
\hline Drug regime & $\begin{array}{l}\text { Con- } \\
\text { tinuous } \\
\text { peni- } \\
\text { cillin }\end{array}$ & $\begin{array}{l}\text { Con- } \\
\text { tinuous } \\
\text { oxytetra- } \\
\text { cycline }\end{array}$ & $\begin{array}{l}\text { Inter- } \\
\text { mittent } \\
\text { peni- } \\
\text { cillin }\end{array}$ & $\begin{array}{l}\text { Inter- } \\
\text { mittent } \\
\text { oxytetra- } \\
\text { cycline }\end{array}$ & $\begin{array}{l}\text { Blank } \\
\text { con- } \\
\text { trols }\end{array}$ \\
\hline $\begin{array}{l}\text { No. admitted to } \\
\text { trial }\end{array}$ & 20 & 20 & 20 & 20 & 25 \\
$\begin{array}{l}\text { No. completed trial } \\
\text { Group mean score }\end{array}$ & 17 & 20 & 17 & 19 & 22 \\
$\begin{array}{l}\text { No. with plus scores } \\
\text { No. with minus }\end{array}$ & 13 & +35 & +41 & +35 & +11 \\
scores & 4 & 19 & 13 & 14 & 11 \\
$\begin{array}{l}\text { No. improved (scores } \\
\text { above +30) }\end{array}$ & 11 & 14 & 11 & 10 & 6 \\
$\begin{array}{l}\text { No. not improved } \\
\text { (scores below +30) }\end{array}$ & 6 & 6 & 6 & 9 & 16
\end{tabular}

The difference between the mean scores of the combined treated groups $\mathrm{A}+\mathrm{B}+\mathrm{D}+\mathrm{E}$ and the combined dummy control groups $\mathrm{C}+\mathrm{F}$ is highly significant $(\mathrm{SD}=8.25, \mathrm{t}=3.27, \mathrm{P}>0.01)$, but no apparent difference exists between the results following continuous therapy in groups $\mathbf{A}+\mathbf{B}$ and those from immediate intermittent therapy in groups $\mathbf{D}+\mathbf{E}\left(\chi^{2}=0.71, \mathbf{P}<0.30\right)$. Similarly, $\mathbf{K}$ phenoxymethyl penicillin (groups $A+D$ ) is as effective as oxytetracycline (groups $\mathrm{B}+\mathrm{E})\left(\chi^{2}=\right.$ $0.072, P<0.70)$, and this is true whether the antibiotics are used continuously or intermittently, 
TABLE IV

MEAN NUMBER AND DURATION OF ACUTE CHEST EPISODES RELATED TO CLINICAL RESPONSE

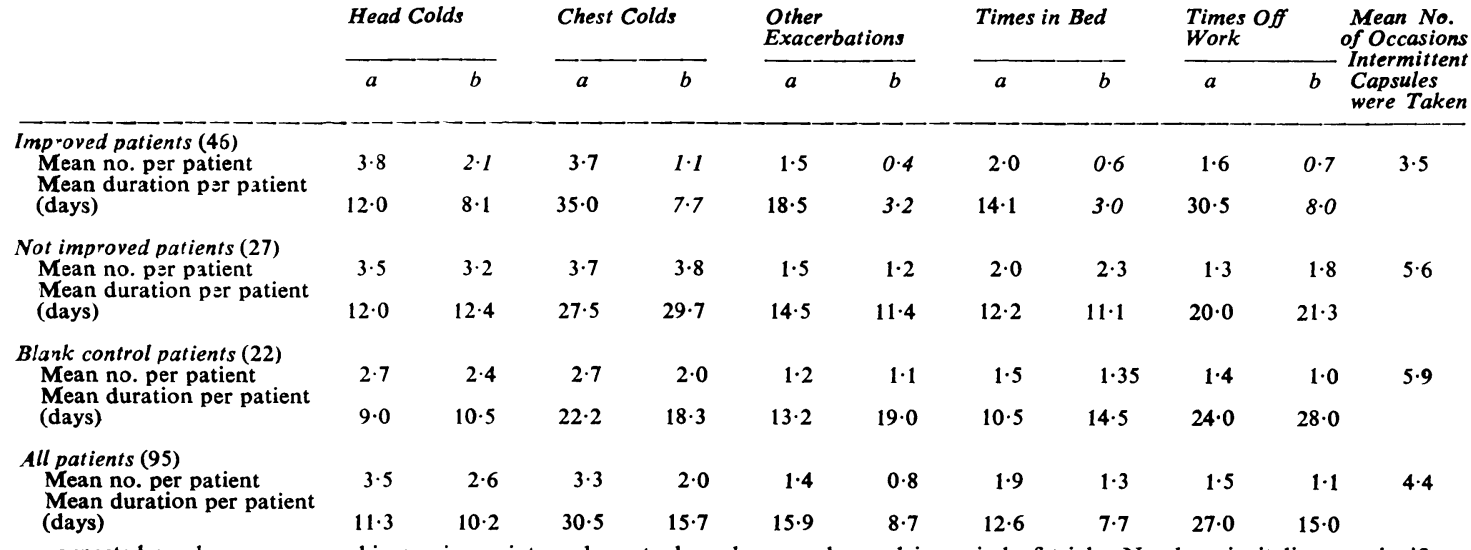

$a=$ expected numbers, as occurred in previous winter. $b=$ actual numbers, as observed in period of trial. Numbers in italics are significant at the $5 \%$ level compared to the previous year.

TABLE V

NUMBER AND DURATION OF EPISODES RELATED TO TREATMENT GROUP

\begin{tabular}{|c|c|c|c|c|c|c|c|c|}
\hline & \multicolumn{2}{|c|}{$\begin{array}{l}\text { Continuous } \\
\text { Penicillin }\end{array}$} & \multicolumn{2}{|c|}{$\begin{array}{l}\text { Continuous } \\
\text { Oxytetracycline }\end{array}$} & \multicolumn{2}{|c|}{$\begin{array}{l}\text { Intermittent } \\
\text { Penicillin }\end{array}$} & \multicolumn{2}{|c|}{$\begin{array}{l}\text { Intermittent } \\
\text { Oxytetracycline }\end{array}$} \\
\hline & (i) & (ii) & (i) & (ii) & (i) & (ii) & (i) & (ii) \\
\hline $\begin{array}{l}\text { Improved patients (46) } \\
\text { Head colds } \\
\text { Chest colds } \\
\text { Other exacerbations } \\
\text { Times confined to bed } \\
\text { Occasions off work }\end{array}$ & $\begin{array}{l}2 \cdot 3 \\
1 \cdot 0 \\
0 \cdot 7 \\
0 \cdot 7 \\
0 \cdot 5\end{array}$ & $\begin{array}{r}10 \cdot 0 \\
11 \cdot 5 \\
4 \cdot 6 \\
3 \cdot 5 \\
4 \cdot 0\end{array}$ & $\begin{array}{l}2 \cdot 3 \\
1 \cdot 1 \\
0 \cdot 2 \\
0 \cdot 4 \\
0 \cdot 7\end{array}$ & $\begin{array}{l}6 \cdot 8 \\
6 \cdot 7 \\
0 \cdot 7 \\
1 \cdot 4 \\
7 \cdot 0\end{array}$ & $\begin{array}{l}2.7 \\
0.9 \\
0.4 \\
0.7 \\
0.6\end{array}$ & $\begin{array}{r}11 \cdot 0 \\
7 \cdot 3 \\
3 \cdot 9 \\
3 \cdot 4 \\
5 \cdot 0\end{array}$ & $\begin{array}{l}2 \cdot 1 \\
1.6 \\
0 \cdot 5 \\
0 \cdot 8 \\
0.4\end{array}$ & $\begin{array}{l}9 \cdot 0 \\
9 \cdot 8 \\
4 \cdot 4 \\
4 \cdot 8 \\
9.0\end{array}$ \\
\hline $\begin{array}{l}\text { Not improved patients (27) } \\
\text { Head colds } \\
\text { Chest colds } \\
\text { Other exacerbations } \\
\text { Times confined to bed } \\
\text { Occasions off work }\end{array}$ & $\begin{array}{l}2 \cdot 2 \\
3 \cdot 2 \\
1 \cdot 2 \\
1 \cdot 8 \\
1 \cdot 2\end{array}$ & $\begin{array}{r}8 \cdot 1 \\
17 \cdot 5 \\
9 \cdot 7 \\
8 \cdot 0 \\
11 \cdot 5\end{array}$ & $\begin{array}{l}4 \cdot 5 \\
5 \cdot 2 \\
1 \cdot 8 \\
3 \cdot 0 \\
4 \cdot 0\end{array}$ & $\begin{array}{l}18 \cdot 3 \\
45 \cdot 0 \\
17 \cdot 5 \\
17 \cdot 7 \\
49 \cdot 0\end{array}$ & $\begin{array}{l}3 \cdot 7 \\
4 \cdot 2 \\
1 \cdot 0 \\
2 \cdot 7 \\
1 \cdot 5\end{array}$ & $\begin{array}{r}13 \cdot 0 \\
29 \cdot 0 \\
5 \cdot 0 \\
11 \cdot 0 \\
5 \cdot 1\end{array}$ & $\begin{array}{l}2 \cdot 6 \\
2 \cdot 4 \\
1 \cdot 0 \\
1 \cdot 9 \\
2 \cdot 2\end{array}$ & $\begin{array}{r}10 \cdot 0 \\
16 \cdot 0 \\
6 \cdot 0 \\
9 \cdot 0 \\
19 \cdot 0\end{array}$ \\
\hline
\end{tabular}

(i) Mean number of episodes per patient. (ii) Mean duration per patient days). Numbers in italics are significant at the $5 \%$ level compared to the blank control as shown in Table IV.

whilst each is significantly better than the dummy control group $(P$ (exact test $)=0 \cdot 018)$.

As all the antibiotic regimes were equally effective, the experiences of those patients classified as improved can be compared with those considered to be not improved. The mean number of episodes or experiences during the course of the trial, and during the comparable period in the previous winter for which records had previously been maintained, is shown in Table IV. The number and duration of head colds in the not improved group is the same in the two successive winters, but in the improved group there is a significant reduction in the number of head colds during the course of the antibiotic trial $(\mathrm{SD}=0 \cdot 39$, $\mathrm{t}=3.58, \mathrm{P}>0.01$ ).

The improved group shows a significant reduction in the number and duration of all acute chest exacerbations whatever their cause, and in the number and duration of periods confined to bed or off work. No such difference is observed between two successive winters in the not improved group. Moreover, when the mean number of episodes and the mean duration of these episodes per patient in the improved and not improved groups are related to treatment regimes (Table V), it is again seen that the improved patients show an equal and significant reduction in the number and duration of most of these episodes irrespective of the drug regime employed. Again no such significant difference is observed in the not improved patients.

When the various episodes are related to treatment groups only, irrespective of the type of response, a different situation is observed (Table VI). The number of head colds, chest exacerba- 
TABLE VI

MEAN FREQUENCY AND DURATTON OF ACUTE CHEST EPISODES, RELATED TO THERAPEUTIC REGIMES

\begin{tabular}{|c|c|c|c|c|c|c|c|}
\hline & \multirow{2}{*}{$\begin{array}{l}\text { Expected } \\
\text { Experiences } \\
\text { (average for } \\
\text { previous } \\
\text { winter) }\end{array}$} & \multicolumn{6}{|c|}{ Actual Experiences (Average Observed During the Trial) } \\
\hline & & $\begin{array}{l}\text { All } \\
\text { Patients }\end{array}$ & $\begin{array}{l}\text { Continuous } \\
\text { Therapy }\end{array}$ & $\begin{array}{l}\text { Intermittent } \\
\text { Therapy }\end{array}$ & $\begin{array}{l}\text { Peni- } \\
\text { cillin }\end{array}$ & $\begin{array}{l}\text { Oxytetra- } \\
\text { cycline }\end{array}$ & Controls \\
\hline No. of patients in sample & 95 & 95 & 37 & 36 & 34 & 39 & 22 \\
\hline $\begin{array}{l}\text { Mean no. of head colds } \\
\text { Mean duration per patient (days) }\end{array}$ & $\begin{array}{r}3 \cdot 5 \\
11 \cdot 3\end{array}$ & $\begin{array}{r}2 \cdot 6 \\
10 \cdot 2\end{array}$ & $\begin{array}{l}2 \cdot 6 \\
9 \cdot 9\end{array}$ & $\begin{array}{r}2 \cdot 7 \\
10 \cdot 5\end{array}$ & $\begin{array}{r}2 \cdot 7 \\
10 \cdot 7\end{array}$ & $\begin{array}{r}2 \cdot 7 \\
11 \cdot 1\end{array}$ & $\begin{array}{r}2 \cdot 4 \\
10 \cdot 5\end{array}$ \\
\hline $\begin{array}{l}\text { Mean no. of all chest exacerbations } \\
\text { Mean duration per patient (days) }\end{array}$ & $\begin{array}{r}4 \cdot 7 \\
46 \cdot 4\end{array}$ & $\begin{array}{r}2 \cdot 8 \\
24 \cdot 2\end{array}$ & $\begin{array}{r}2 \cdot 8 \\
22 \cdot 0\end{array}$ & $\begin{array}{r}2 \cdot 7 \\
19 \cdot 0\end{array}$ & $\begin{array}{r}2 \cdot 7 \\
19 \cdot 7\end{array}$ & $\begin{array}{r}2 \cdot 9 \\
21 \cdot 3\end{array}$ & $\begin{array}{r}3 \cdot 1 \\
37 \cdot 3\end{array}$ \\
\hline $\begin{array}{l}\text { Mean no. of times confined to bed } \\
\text { Mean duration per patient (days) }\end{array}$ & $\begin{array}{r}1.9 \\
12 \cdot 6\end{array}$ & $\begin{array}{l}1 \cdot 3 \\
7 \cdot 7\end{array}$ & $\begin{array}{c}1 \cdot 1 \\
5 \cdot 7\end{array}$ & $\begin{array}{l}1 \cdot 35 \\
6 \cdot 5\end{array}$ & $\begin{array}{c}1 \cdot 27 \\
5 \cdot 6\end{array}$ & $\begin{array}{l}1 \cdot 23 \\
6 \cdot 5\end{array}$ & $\begin{array}{l}1 \cdot 35 \\
14 \cdot 5\end{array}$ \\
\hline $\begin{array}{l}\text { Mean no. of occasions off work } \\
\text { Mean duration per patient (days) }\end{array}$ & $\begin{array}{r}1 \cdot 5 \\
27 \cdot 0\end{array}$ & $\begin{array}{r}1 \cdot 1 \\
14 \cdot 0\end{array}$ & $\begin{array}{r}1 \cdot 0 \\
10 \cdot 8\end{array}$ & $\begin{array}{r}1 \cdot 1 \\
13 \cdot 0\end{array}$ & $\begin{array}{r}1 \cdot 0 \\
10 \cdot 8\end{array}$ & $\begin{array}{r}1 \cdot 2 \\
11 \cdot 2\end{array}$ & $\begin{array}{r}1 \cdot 0 \\
28 \cdot 0\end{array}$ \\
\hline $\begin{array}{l}\text { No. of hospital admissions: } \\
\text { Total in all patients admitted to trial } \\
\text { Excluded from final analysis } \\
\text { Retained in final analysis }\end{array}$ & $\frac{7}{7}$ & $\begin{array}{r}11 \\
4 \\
7\end{array}$ & 二 & $\begin{array}{l}3 \\
2 \\
1\end{array}$ & $\begin{array}{l}1 \\
1 \\
-\end{array}$ & $\begin{array}{l}2 \\
1 \\
1\end{array}$ & $\begin{array}{l}8 \\
2 \\
6\end{array}$ \\
\hline
\end{tabular}

Numbers in italics are significant at the $5 \%$ level when compared with the corresponding control mean.

tions, and occasions off work, i.e., frequency of exacerbations, is the same in each of the therapeutic regimes and in the control group. The number of occasions of confinement to bed, i.e., severity, however, is reduced both in the oxytetracycline and in the continuous therapy groups. The duration of periods of confinement to bed was reduced in each of the therapeutic regimes under test. A greater number of patients in the control group was admitted to hospital than in the combined intermittently treated groups $\mathrm{D}+\mathrm{E}\left(\chi^{2}\right.$ (with Yates correction) $=5 \cdot 28, P=0 \cdot 02$ ). The difference in hospital admission rates between the intermittently and continuously treated groups of patients is probably not significant ( $P$ (Fisher's exact test $)=0 \cdot 115$ ).

Hence antibiotic therapy of the chronic bronchitic is valuable in reducing the duration and the severity of the acute exacerbations though not necessarily their frequency. But little difference is to be observed between continuous daily therapy and immediate intermittent treatment, or between an oral penicillin and a broad spectrum tetracycline.

VENTILATORY FUNCTION Ventilatory function was assessed by measuring the one second forced expiratory volume (F.E.V. $\left.\cdot_{1.0}\right)$ and the forced vital capacity (F.V.C.), using a modified Gaensler type of spirometer, and by estimating peak expiratory flow (E.F.R.) using Wright's peak flow meter. Regular monthly readings are available for 92 of the 95 patients who completed this trial. The mean F.E.V $\cdot_{1.0}$ for all the participants in the trial shows an overall decline over the six months' observation period of about 0.07 litre, being a reduction of about $5 \%$ (Table VII). The decline, however, was
TABLE VII

CHANGE IN F.E.V. $\cdot{ }_{10}$ DURING THE COURSE OF THE TRIAL RELATED TO TREATMENT GROUPS

\begin{tabular}{|c|c|c|c|c|}
\hline \multirow{2}{*}{$\begin{array}{l}\text { Treatment } \\
\text { Group }\end{array}$} & \multirow{2}{*}{$\begin{array}{l}\text { Mean } \\
\text { F.E.V.1·0 } \\
\text { at Start } \\
\text { (litres) }\end{array}$} & \multicolumn{3}{|c|}{ Change in Mean F.E.V.1.0 at Finish (litres) } \\
\hline & & $\begin{array}{l}\text { Whole } \\
\text { Group }\end{array}$ & $\begin{array}{l}\text { Improved } \\
\text { Patients }\end{array}$ & $\begin{array}{l}\text { Not } \\
\text { Improved } \\
\text { Patients }\end{array}$ \\
\hline $\begin{array}{c}\text { A } \\
\text { B } \\
\text { D } \\
\text { E } \\
\text { C+F } \\
\text { All groups }\end{array}$ & $\begin{array}{l}1.43 \\
1.46 \\
1.67 \\
1.48 \\
1.44 \\
1.50\end{array}$ & $\begin{array}{l}-0.03 \\
-0.08 \\
-0.07 \\
-0.05 \\
-0.07 \\
-0.07\end{array}$ & $\begin{array}{l}-0.07 \\
-0.06 \\
-0.04 \\
-0.03 \\
-0.08 \\
-0.05\end{array}$ & $\begin{array}{l}-0.01 \\
-0.15 \\
-0.12 \\
-0.10 \\
-0.07 \\
-0.11\end{array}$ \\
\hline
\end{tabular}

more marked in those patients assessed as being not improved $(0 \cdot 11$ litre) than in those patients classified as improved $(0.05$ litre $)$. All groups experienced an initial improvement in the mean F.E.V..$_{1.0}$ during the first month of treatment. Following this a more or less steady fall developed through the succeeding winter months, and this was followed by a rise which, however, in no group reached the original mean F.E.V..$_{1.0}$ start value. The combined control group $C+F$ showed a maximal fall of the F.E.V $\cdot_{1.0}$ in December, whereas intermittent $K$ phenoxymethyl penicillin therapy (group D) reduced the size of this trough and delayed its appearance until January. Continuous $K$ phenoxymethyl penicillin therapy (group A) apparently postponed the winter trough even longer, until February, but the pattern of F.E.V. variations otherwise closely resembled that of the control group. Following intermittent oxytetracycline therapy (group E) the seasonal fluctuations were less extreme than those associated with continuous $\mathbf{K}$ phenoxymethyl penicillin, whereas continuous oxytetracycline therapy (group B) produced a trough in January which was followed by a much steeper rise than 
TABLE VIII

VARIATION OF THE MEAN VENTILATORY VOLUMES RELATED TO THERAPY AND TO CLINICAL RESPONSE

\begin{tabular}{|c|c|c|c|c|c|c|c|c|c|}
\hline \multirow{2}{*}{$\begin{array}{l}\text { Drug } \\
\text { Regime }\end{array}$} & \multicolumn{3}{|c|}{ Mean F.E. $V_{\cdot 1 \cdot 0}$ (litres) } & \multicolumn{3}{|c|}{ Mean E.F.R. (litres/min.) } & \multicolumn{3}{|c|}{ Mean F.V.C. (litres) } \\
\hline & Before & After & Change & Before & After & Change & Before & After & Change \\
\hline $\begin{array}{c}\mathbf{A} \\
\mathbf{B} \\
\mathbf{D} \\
\mathbf{E} \\
\mathbf{C}+\mathbf{F} \\
\text { All improved } \\
\text { Not improved }\end{array}$ & $\begin{array}{l}1.43 \\
1.46 \\
1.67 \\
1.48 \\
1.44 \\
1.58 \\
1.45\end{array}$ & $\begin{array}{l}1 \cdot 40 \\
1 \cdot 38 \\
1 \cdot 60 \\
1 \cdot 43 \\
1 \cdot 37 \\
1 \cdot 53 \\
1 \cdot 34\end{array}$ & $\begin{array}{l}-0.03 \\
-0.08 \\
-0.07 \\
-0.05 \\
-0.07 \\
-0.05 \\
-0.11\end{array}$ & $\begin{array}{l}217 \\
210 \\
276 \\
238 \\
184 \\
233 \\
217\end{array}$ & $\begin{array}{l}208 \\
204 \\
258 \\
227 \\
183 \\
226 \\
206\end{array}$ & $\begin{array}{r}-9 \\
-6 \\
-18 \\
-11 \\
-1 \\
-7 \\
-11\end{array}$ & $\begin{array}{l}2 \cdot 80 \\
2 \cdot 74 \\
3 \cdot 27 \\
2 \cdot 77 \\
2 \cdot 38 \\
2 \cdot 78 \\
2 \cdot 79\end{array}$ & $\begin{array}{l}2 \cdot 75 \\
2 \cdot 63 \\
3 \cdot 23 \\
2 \cdot 70 \\
2 \cdot 39 \\
2 \cdot 83 \\
2 \cdot 67\end{array}$ & $\begin{array}{l}-0.05 \\
-0.11 \\
-0.04 \\
-0.07 \\
+0.01 \\
+0.05 \\
-0.12\end{array}$ \\
\hline
\end{tabular}

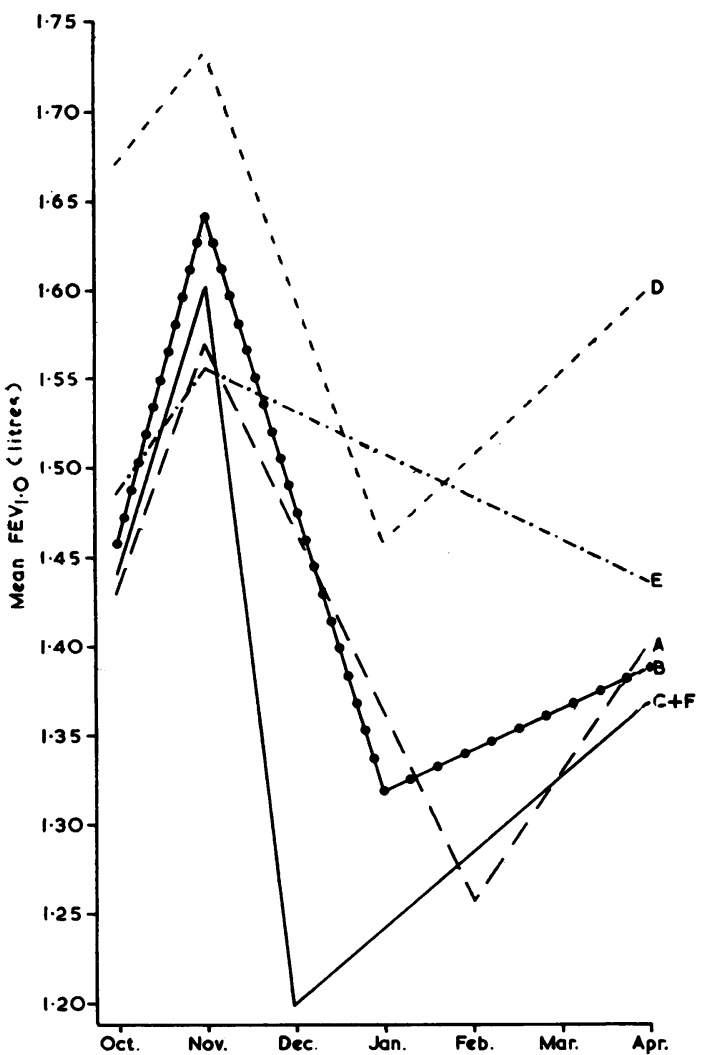

FIG. 1. Diagrammatic pattern of monthly variations in F.E.V.1.0. - - $A$ Continuous penicillin. $-\bullet-B$ Continuous oxytetracycline. penicillin. -.-.- $E$ Intermittent oxytetracycline. $C+F$ Blank controls.

in any other treatment group. These general characteristics are shown diagrammatically in Fig. 1. Increase in the final F.E.V. $\cdot_{1 \cdot 0}$ after six months' winter therapy, compared with the value at the start of the trial, occurred in as many patients in each of the treatment groups as in the controls, and in as many of the improved patients as in the not improved group. Reduction of the F.E.V. ${ }_{\cdot{ }_{1 \cdot 0}}$ at the end of the trial, however, appeared more frequently than did an increase, and it occurred more frequently in the not improved than in the improved patients. The mean values of the F.V.C. and the E.F.R. followed closely the variations in the comparable F.E.V..$_{1 \cdot 0}$ estimations; the variations in start and finish values of these ventilatory function tests are shown in Table VIII.

BACTERIOLOGY Sputum specimens were obtained before starting treatment, at each attendance during the course of the investigation, and at the end of the trial. No evidence was obtained that sterilization of an infected sputum was achieved by any of the drug regimes we employed. In 85 of the 95 patients who finished the trial for whom complete records were available for analysis, the sputum remained infected throughout, and in those other patients with incomplete bacteriological records no significant change appeared in the flora of their sputum specimens. No significant changes were observed in the drug sensitivity patterns of any of the strains of Haemophilus influenzae or the pneumococcus recovered from patients during the trial. Three patients showed penicillin-resistant strains of Staphylococcus aureus; one occurred in a patient in group $\mathbf{A}$ (continuous $\mathbf{K}$ phenoxymethyl penicillin therapy) in the third month of treatment, one occurred in a patient in the control group in the second month of the trial after admission to hospital, and the third example also occurred in a control patient in the fourth month, also after admission to hospital. One other patient in group B (continuous oxytetracycline therapy) showed persistence of a penicillin and tetracycline resistant strain of $\boldsymbol{H}$. influenzae throughout the course of the trial and was finally assessed as being clinically improved. In addition, another control patient developed a Pseudomonas proteus superinfection, and Monilia albicans was usually present in the sputum specimens from nine other patients, irrespective of therapy. 


\section{DISCUSSION}

The difficulties inherent in the assessment of clinical trials in patients with chronic bronchitis are many. Patients' statements as to their previous history are frequently unreliable (Ogilvie and Newell, 1960). Therefore patients admitted to these trials should probably have been under previous prolonged observation. Moreover, the ill-defined nature of an exacerbation of chronic bronchitis, which has been stressed by Elmes, Fletcher, and Dutton (1957), makes evaluation in clinical trials rather unsatisfactory if expressed only in terms of frequency, duration, or severity of exacerbations. The main disability of established bronchitis arises from loss of working time, or time spent in bed as a result of acute exacerbations, but additionally there are also variations in the day to day disability due to variations in the severity of symptoms.

Ritchie (1958) suggested that the symptoms of the common cold may be due to invasion of the tissues by bacteria normally present in the nasopharynx. This hypothesis has obtained support from McKerrow, Oldham, and Thomson (1961), who treated normal subjects and patients with pneumoconiosis and some degree of bronchitis with $45 \mathrm{mg}$. of a tetracycline daily for three days starting at the earliest symptoms of a cold. They found that the proportion of all first colds cured in three days was the same in both their groups of patients. Like Elmes et al. (1957), Fear and Edwards (1962) have also observed that intermittent treatment for seven days only of the fully developed acute exacerbation of bronchitis results solely in a reduction of the duration of the exacerbation, but of a lesser degree than that following continuous therapy. The present study appears to lend support to the hypothesis of Ritchie (1958); and, by demonstrating a reduction not only in the duration but also in the number of exacerbations experienced by the improved patients (Table V), it underlines the importance of starting treatment at the earliest possible moment in order to obtain maximal effect.

The results following intermittent treatment of an established chronic bronchitic, starting immediately at the onset or at least within an hour or two of the start of a head cold and before pulmonary symptoms develop or are increased, with $1 \mathrm{~g}$. of a broad spectrum antibiotic daily for seven days are as good as the results achieved by continuous treatment of the bronchitic with the same drug dosage.

Most previous studies have demonstrated a reduction in the duration of acute exacerbations rather than in their number. In this present survey not only has the duration of the periods off work or confined to bed as a result of chest exacerbations been reduced, but the actual number of such episodes has also been reduced, and the reduction is significant at the $5 \%$ level in those patients whose clinical response was assessed as improved.

Patient cooperation was of a high order, although several patients failed to take the special capsules sufficiently early. Yet most patients took the intermittent therapy more frequently than was apparently necessary (Table IV) because, although each bronchitic in the trial suffered a mean of 2.6 head colds, the special capsules were used for an average of 4.4 occasions per patient during the six winter months. However, for the cost of four to five periods of seven days' treatment with $1 \mathrm{~g}$. of penicillin- $\mathrm{V}$ or oxytetracycline per day, results comparable to those achieved with continuous daily therapy can be obtained in suitable patients. The drug bill can thus be reduced by about $80 \% .^{1}$ We therefore agree with Elmes and his colleagues (1957) that patients should be provided with a supply of antibiotic to take without consultation immediately at the start of a head cold, provided that the patients clearly understand the instructions.

Needham, Rogan, and McDonald (1954), Gilson (1959), Higgins and Cochrane (1961), and Tinker (1961) have shown that ventilatory function declines with age. Higgins and Cochrane (1961) suggested that the difference in the mean F.E..$_{0.75}$ of unselected non-miners between the two decades 45 to 54 and 55 to 64 amounts to about 0.46 litre and that the general rate of decline is of the order of $0.04-0.05$ litre per year. In this series of bronchitics the mean decline is about 0.07 litre in the six months' observation, so that apparently the rate of decline is accelerated in chronic bronchitis. However, the rate of decline in treated patients considered to be improved was about half that of the patients who were not improved. Improvement of the F.E.V. estimations occurred as frequently in the treated patients as in the controls, and as frequently in those patients assessed as improved as in those not improved. Likewise reduction of the F.E.V. occurred as often in the patients treated with antibiotics as in the controls, and was unrelated to the type of antibiotic used or whether the antibiotic was used

\footnotetext{
1 Intermittent penicillin-V for 7 days on each of 5 occasions costs $£ 412 \mathrm{~s}$. Intermittent oxytetracycline for 7 days on each of 5 occasions cos:s £9 $13 \mathrm{~s}$.

Continuous penicillin-V daily for 175 days costs $£ 22$ 19s. 8d. Continuous oxytetracycline daily for 175 days costs $£ 48$.
} 
continuously or intermittently. The patients on continuous therapy, however, appear to deteriorate less rapidly than those on intermittent therapy. The F.E.V. shows considerable variation throughout the winter months. In the untreated bronchitic a fall in the F.E.V. occurs, which is maximal in December, to produce a trough and is then followed by a rise which rarely regains the start level.

Some writers (Lancet, 1960) assume that chemoprophylaxis is used in bronchitis to obtain effective chemotherapy against the common potential pathogens. Sterilization of the sputum in chronic bronchitis is difficult to attain but was claimed to have been achieved by Noach, as quoted in the Lancet (1960), with antibiotics whilst the patients remained in bed in hospital. Persistent eradication of bronchial infection has never been achieved by us in any of our out-patient trials, irrespective of the drugs or dosage we have employed, although significant clinical improvement has been achieved with sustained antibiotic therapy. Cooper, Williamson, Zinnemann, Edwards, and Thornton (1961) have shown by repeated bacterial counts that long-term oxytetracycline therapy does not in fact effect any appreciable reduction in counts of statistical significance, except when acute exacerbations occur, and the reduction is then confined to $H$. influenzae alone.

Two patients who acquired drug-resistant staphylococci in their sputum did so following treatment in hospital. This seems to be of some importance since, of 11 hospital admissions, eight occurred in the untreated control group of patients, and it was in two of these that drug-resistant staphylococcal infections took place. None of the patients who remained at home, irrespective of the progress of their bronchitis or of their treatment, acquired such superinfection. The development of infections of the respiratory and intestinal tracts due to drug-resistant staphylococci or to fungi is uncommon, and the reputed dangers of continuous antibiotics may well be less frequent than was assumed to be the case in the past.

Antibiotic therapy in the chronic bronchitic is valuable in controlling his symptoms (Edwards, Buckley, Fear, Williamson, and Zinnemann, 1957), in reducing the duration and severity of acute exacerbations, though not necessarily their frequency, and in delaying the expected rate of deterioration of ventilatory function. Little difference occurs between the results following daily continuous therapy and immediate intermittent treatment, or in fact between an oral penicillin and oxytetracycline.

\section{SUMMARY}

Ninety-five patients with established chronic bronchitis were observed as out-patients through six winter months during a double blind investigation employing $\mathrm{K}$ phenoxymethyl penicillin, 500 mg. b.d., or oxytetracycline, $500 \mathrm{mg}$. b.d. The antibiotics were taken either continuously every day throughout the observation period or intermittently for periods of seven days only, starting immediately at the onset of a head cold and before the development of overt symptoms of a chest exacerbation.

The results following immediate intermittent therapy were as good as those following continuous treatment, and both were significantly better than the results observed in the blank control groups. A simple marking system used to assess response to treatment permitted classification of response as 'improved' or 'not improved'. The method readily lends itself to statistical analysis.

There was no significant difference in the number of head colds, chest exacerbations, and occasions off work between the treated groups and the control groups, but the treated groups all showed a significant reduction in the duration of these exacerbations.

Those patients who were assessed as being clinically improved at the end of the trial showed a significant reduction in the number and the duration of the various kinds of chest exacerbations discussed, whereas the patients assessed as being not improved by the treatment showed no difference in the number and duration of exacerbations compared with previous experience and records.

Sterilization of the sputum was not obtained with any of the drug regimes employed, nor was there any evidence of the acquisition or development of drug-resistant organisms in the patients treated with antibiotics. The only patients to develop drug-resistant staphylococcal bronchial infections were two in the untreated blank control groups following a period in hospital.

Variations in the F.E.V $\cdot_{1.0}$ during the winter months of 1959 to 1960 have been studied in 95 chronic bronchitic patients under treatment and observation.

We are indebted to Dr. G. M. Williamson, late of, and Dr. Edith Robinson, of the University of Leeds, for advice on the statistical procedures employed; and to Dr. G. B. Ludlam of the Public Health Laboratory Service, Leeds, and Dr. H. T. Levi of Seacroft Hospital, Leeds, for the bacteriological and other 
laboratory investigations carried out during the course of these trials. We are particularly grateful to other members past and present of the medical and nursing staff of the Leeds Department of Respiratory Diseases for their constant help in the conduct of the trials. Finally we wish to thank Dr. A. Brunton of Messrs. Pfizer Ltd. for the supplies of Terramycin SF and the appropriate dummies, and Messrs. Eli Lilly \& Co. Ltd., who made a generous grant towards the expenses of the trial and provided the V-Cil-K and corresponding dummy capsules.

\section{REFERENCES}

Cooper, A. W., Williamson, G. M., Zinnemann, K., Edwards, G. F., and Thornton, H. (1961). Brit. J. Dis. Chest, 55, 23.
Edwards, G., Buckley, A. R., Fear, E.'C., Williamson, G. M., and Zinnemann, K. (1957). Brit. med. J., 2, 259.

Elmes, P. C., Fletcher, C. M., and Dutton, A. A. C. (1957). Ibid., 2, 1272.

Fear, E. C., and Edwards, G. F. (1962). Brit. J. Dis. Chest, 56, 153.

Gilson, J. C. (1959). In Proc. Pneumoconiosis Conference, Johannesburg, 1959, ed. A. J. Orenstein, p. 280. Churchill, London.

Higgins, I. T. T., and Cochrane, A. L. (1961). Brit. J. industr. Med., $18,93$.

Lancet (1960), 2, 1286.

McKerrow, C. B., Oldham, P. D., and Thomson, S. (1961). Lancet, $1,185$.

Needham, C. D., Rogan, M. C., and McDonald, I. (1954). Thorax, 9 , 313.

Ogilvie, A. G., and Newell, D. J. (1960). Brit. J. Dis. Chest, 54, 308.

Ritchie, J. M. (1958). Lancet, 1, 618.

Tinker, C. M. (1961). Brit. med. J., 1, 1365. 